УДК 811.111 '22’42

DOI https://doi.org/10.26661/2414-1135-2021-84-21

\title{
СПЕЦИФІКА МУЛЬТИМОДАЛЬНИХ ЛЕКСЕМ ТА СИНТАКСИЧНИХ КОНСТРУКЦІЙ У СУЧАСНІЙ АНГЛОМОВНІЙ РЕКЛАМІ
}

\author{
Макарук Л. Л. \\ доктор філологічних наук, дочент, \\ професор кафедри прикладної лінгвістики \\ Волинський національний університет імені Лесі Украӥнки \\ просп. Волі, 13, Луцььк, Волинська область, Україна \\ orcid.org/0000-0002-8988-2753 \\ laryssa_makaruk@ukr.net
}

\section{Ключові слова:}

мультимодальна лексема, мультимодальна синтаксична конструкція, засоби, знак.
Статтю присвячено дослідженню мультимодальних лексем i синтаксичних конструкцій. На основі проаналізованого ілюстративного матеріалу встановлено, що частина сучасних англомовних синтаксичних конструкцій змінила свій статус із мономодальних на мультимодальні. Причиною слугує інформаційна революція, яка уможливлює імплементацію комунікаційних трансформацій на всіх можливих рівнях, починаючи від графічного й завершуючи текстовим. Установлено, що кількість засобів невербальної природи, які входять до складу однієї синтаксичної конструкції, не фіксована й варіюється залежно від кожного конкретного випадку. Серед них трапляються такі, в яких фігурує лише один складник невербальної природи або кілька в рамках однієї лексеми чи синтаксичної конструкції загалом. Ідентифіковано й такі, в яких немає жодного вербального складника. Вибір відповідної одиниці невербальної природи зумовлений тематикою та переважно відповідає змісту тексту. У корпусі ілюстративного матеріалу виявлено низку невербальних одиниць, які максимально уподібнюють заміщуваній лексемі задля забезпечення читабельності й упізнаваності. Вартим уваги $\epsilon$ й той факт, що часто до складу мультимодальної лексеми входить один складник невербальної природи, який є віддзеркаленням повної назви продукту. Це свідчить про зміну семіотичних парадигм і потребу в переосмисленні наявних підходів до розгляду знаків і знакових систем, оскільки спостерігаємо існування знака в знакові, що є цілковитим дубляжем одного й того ж предмета. Ураховуючи проаналізовані приклади, маємо підстави стверджувати, що мультимодальні лексеми - це одиниці, які утворені шляхом поєднання виключно невербальних одиниць, що за формою відповідають кодифікованим алфавітним графемам; або вербальних i невербальних кодифікованих графем, сукупність яких утворює одиницю, яка на відміну від класичної лексеми має не лише відмінний план вираження, але й певною мірою трансформує план змісту. 


\title{
SPECIFIC FEATURES OF ENGLISH-LANGUAGE MULTIMODAL LEXICAL UNITS AND SYNTACTIC STRUCTURES IN MODERN ADVERTISEMENTS
}

\author{
Makaruk L. L. \\ Doctor of Philology, Associate Professor, \\ Professor at the Department of Applied Linguistics \\ Lesya Ukrainka Volyn National University \\ Volia Ave., 13, Lutsk, Volyn region, Ukraine \\ orcid.org/0000-0002-8988-2753 \\ laryssa_makaruk@ukr.net
}

Key words: multimodal lexeme, multimodal syntactic construction, device, sign.
This article is devoted to the study of multimodal lexical units and syntactic constructions. Taking into account the illustrative material which has been analysed, it has been identified that a certain portion of modern Englishlanguage lexical units as well as syntactic constructions have changed its status from monomodal to multimodal. Information revolution served as a key reason for that and made it possible to implement communication transformations at all levels, from graphic to textual. It has been shown that the number of non-verbal devices which are included in a single syntactic construction is not fixed, and varies in each case. Among these constructions there are some in which there is only one component of a non-verbal nature, or several within one lexical unit or a syntactic construction in general. Those which do not contain any verbal components have also been identified. The choice of a non-verbal unit which is appropriate in each case is determined by the subject and primarily corresponds to the content of the text. A number of non-verbal units which were identified in the corpus of the exemplifying material are very similar to the substituted lexical unit. This technique is used to ensure comprehensibility of an advertisement. It should also be noted that the multimodal lexeme often includes one non-verbal component which reflects the full name of the product which is being advertised. This indicates a change in semiotic paradigms and the need to rethink existing approaches to the consideration of signs and sign systems, as we observe the utilization of a pictorial sign within a lexical unit which duplicates the actual sense of the lexical unit itself. On the basis of the examples which have been analysed, we have a reason to conclude that multimodal lexemes are units which are formed by combining exclusively non-verbal units which correspond in form to the codified alphabetic graphemes; or verbal codified graphemes and nonverbal ones which combination forms a unit which differs from the classical one. Multimodal units not only embody a different plan of expression, but also to some extent transforms the plan of the content.
Постановка проблеми та її актуальність. Значний відсоток сучасного англомовного мас-медійного комунікативного простору займає реклама, яка нині увиразнюється шляхом входження до іiі складу компонентів, різних за структурою, формою, розмірами, кількістю. Корпус ілюстративного матеріалу свідчить, що всі засоби, які використовують під час створення реклами, можна диференціювати на вербальні, паравербальні й невербальні. Закономірно, що продуцентам доводиться боротися за свого прихильника й, вочевидь, шукати такі способи й засоби інформування, які здатні утримати наявну кількість зацікавлених осіб, завоювати прихильність нових, щоб максимально збільшити свою аудиторію, а отже, і можливі прибутки. Ураховуючи означене різноманіття складників, постає потреба в докладному обгрунтуванні їх семантики й комунікативно-прагматичного потенціалу 3 метою виявлення специфіки таких засобів, причин використання та фіксації змін, очевидцями й винуватцями яких ми нині $\epsilon$.

Реклама $є$ потужним інструментом маніпуляції потенційною аудиторією та водночас посередником, який насамперед презентує аудиторії товар чи послугу з метою їх швидкої реалізації. Від правильно сформованої рекламної політики залежить 
успіх і процвітання будь-якої установи, зорієнтованої на конкуренцію поруч з аналогічними альтернативними компаніями, які пропонують відповідній аудиторії свою продукцію чи послуги [4].

Ключовою диференційною ознакою реклами є iï довільність, відхилення від усталених фіксованих норм (орфографічних, граматичних, лексичних, стилістичних), оскільки вона є комерційним продуктом. Реклама позитивно чи негативно впливає на реципієнта, тому важко знайти один оптимальний варіант презентації товару чи послуги, який зміг би заволодіти прихильністю читачів. Це пов'язують із когнітивними механізмами людського мозку. Установлення бажаного контакту в англомовній рекламі відбувається за допомогою різних засобів вербальної, невербальної та паравербальної природи, які апелюють до органів чуттів, активізують роботу мозку, впливаючи на дії та поведінку реципієнтів [4].

Реклама неодноразово перебувала у фокусі уваги вітчизняних і зарубіжних дослідників. Серед них: I.А. Гусейнова [1], В.В. Зірка [2], Т. Кейко [9], Н.С. Лиса [3], Л.Л. Макарук [4-6] О.В. Медвєдєва [7] та інші. Однак належної уваги мультимодальній рекламі приділено не було, що й зумовлює актуальність дослідження.

Мета роботи полягає в докладному аналізі засобів, які використовують для творення мультимодальних лексем і синтаксичних конструкцій, i зумовлює розв'язання таких завдань:

- окреслити специфіку засобів невербальної та паравербальної природи, які виконують роль графем і лексем у сучасному англомовному мас-медійному комунікативному просторі;

- обгрунтувати їх структурні й семантичні особливості;

- на підставі зібраного корпусу ілюстративного матеріалу сформулювати дефініції понять «мультимодальна графема» й «мультимодальна лексема».

Предмет та об'єкт статті. Предметом розвідки є структурні, семантичні й стилістичні особливості невербальних засобів, які використовують для творення мультимодальних графем, лексем і синтаксичних конструкцій. Об' єктом виступають графічні складники, які заміщують кодифіковані графеми й лексеми в сучасній рекламі.

Виклад основного матеріалу дослідження. У роботі звернемо увагу на рекламні тексти, яким характерні девіації на лексичному й синтаксичному рівнях. Під цим розуміємо вкраплення серед кодифікованих графем і / або лексем некодифікованих, які уподібнюють першим і другим шляхом додавання елементів, що розширюють первинні семантичні межі лексеми або синтаксичної конструкції або цілком їх змінюють із метою імітації та тяжіння до максимального наслідування первинного образу відповідного товару відомої торгової марки. Аналізовані приклади уміщують також і інші елементи, які надають тексту особливого забарвлення, а подекуди й впливають на зміст повідомлюваного.

Розглянемо рис. 1, який ілюструє товари компанії McDonald's. У першому мультимодальному реченні Celebrate international Happiness Day у лексемі Happiness спостерігаємо зміну, яка полягає в додаванні стилізованої дужки. Сукупність трьох елементів (двох графем і дужки) нагадує обриси обличчя та формує позитивний емоційний стан. Графеми $s s$ є уособленням очей, а дужка зі штриховими вкрапленнями на обох кінцях $є$ імітацією губ, унаслідок чого розуміємо, що перед нами посмішка. Лексема Happiness має позитивну конотацію, значення якої підсилюється посмішкою, створеною внаслідок поєднання трьох знаків, два 3 яких є алфавітними графемами, а третій належить до спектра знаків пунктуації. Зауважимо, що саме останні дещо видозмінені. I це не випадково, адже така стратегія сприяє акцентуванню на приємних емоціях.

Аналізована лексема неординарна, оскільки внаслідок входження до їі складу дужки мультимодальна. В останні роки спостерігаємо значне збільшення кількості одиниць, яким характерні певні трансформації, що модифікують традиційні одиниці й підсилюють або змінюють їх первинну семантику. Вочевидь, що такі стратегії свідчать про зміни, які відбуваються в сучасному англомовному мас-медійному комунікативному просторі. Отже, як бачимо, до складу лексем можуть входити не лише графеми, а й інші одиниці. Емоція щастя асоціюється з посмішкою, яка, власне, в такому випадку репрезентована завдяки частині лексеми й доповнена дужкою.

На рис. 2, присвяченому рекламі національного свята бубликів, також спостерігаємо наявність мультимодальної лексеми, у складі якої є візуалізований реальний їстівний компонент, що слугує заміщенням графеми “o”. Серед різноманіття бубликів обрано один, який входить до складу лексеми doughnut. Він максимально уподібнений традиційній графемі “o”. Зауважимо, що саме ця графема $\epsilon$ однією із тих, які замінюють найчастіше. Отже, як бачимо, лексема doughnut містить у своєму складі й власне сам бублик, тобто відбувається дублювання назви продукту харчування самим харчовим продуктом, який використано замість графеми “o”.

Знайомлячи 3 такою рекламою, реципієнту мимоволі навіюють образ того об'єкта, заради якого й зроблена реклама, оскільки всюди йдеться про бублики, які на святі роздаватимуть безкоштовно. Таким чином, мультимодальні лексеми слугують не лише оболонками, які номінують, 
описують чи характеризують щось, а й здатні включати до свого складу сам предмет, надавати йому певних ознак, будучи водночас замінником класичної кодифікованої графеми. Аналізована реклама дає підстави стверджувати, що мультимодальна лексема є гетерогенним конструктом, який може вміщувати рекламований товар, що водночас $є$ дублікатором його назви й виконує функцію субституції графеми, яка за структурою відповідає заміщуваному об'єкту.

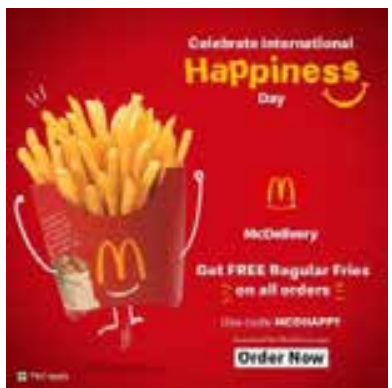

Pис. 1 [16]

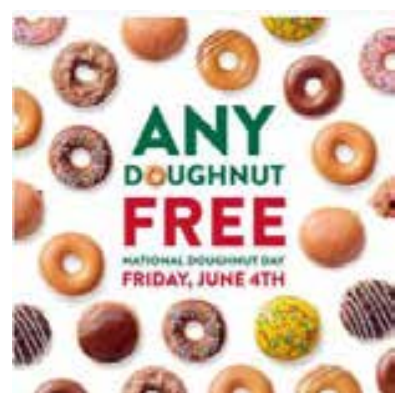

Puc. 2 [16]
Описані вище приклади містять у своєму складі лише один компонент, завдяки якому вони й набувають статусу мультимодального. Звернемо увагу й на інші приклади, які сформовані внаслідок використання продуктів харчування. На рис. 9 помічаємо надпис America, в основі якого лежить гірчиця - традиційний складник хотдогу. Гірчицю оформлено в лексему - назву країни, вихідцем 3 якої є цей популярний продукт. Як бачимо, його представлено на американському стязі. Гірчичний надпис ще раз підкреслює його приналежність до США, чим, вочевидь, пишаються та ще раз акцентують уже за допомогою мініпрапора.

Ще незвичнішою є реклама на рис. 4 та 5, яка сформовані шляхом використання продуктів харчування. Жодна 3 графем на них i, відповідно, лексема завдяки графемі не належить до спектра кодифікованих. Усі вони утворені шляхом використання продуктів, переважно круп, овочів і фруктів. Тому можемо стверджувати, що маємо справу 3 мультимодальними синтаксичними конструкціями. Обидві синтаксичні конструкції добре читабельні. Складники першої конструкції (healthy eating) розміщені поруч із фруктами й овочами; вони менш чіткі й зрозумілі; другої - досить чіткі, в основі іiі графем лежить листя салату, помідор, апельсин, морква, гриб, артишок, кавун, броколі, ананас, перець, яблуко.

Причому для формування речення використано як цілі фрукти й овочі, так і їх частини. Продуценти залучили саме ті елементи, які й справді належать до спектра продуктів здорового харчування. Бачимо, що кодифікованим графемам уподібнено ті продукти, які максимально відповідають їм за формою. Якщо для однієї графеми не підходящою $є$ первинна форма продукту, то до складу лексеми включають iㅣ шматок. Замість двох класичних графем “о” бачимо шматки ананаса й солодкого перцю. Досить неординарне рішення запропоновано й для графем "L" та "T": на місці першої - ціла морква з бадиллям, другоїшматочок гриба.

Таким чином, у сучасному англомовному мас-медійному комунікативному просторі спостерігаємо функціювання синтаксичних конструкцій, лексем і графем, які мають статус мультимодальних. Такі тенденції творення засобів спілкування не випадкові, а продиктовані сучасними вимогами реципієнтів, які, з одного боку, прагнуть до оригінальності й неповторності, а 3 іншого, - намагаються мінімізувати кількість засобів, проте максимізувати їх вплив. Вочевидь, що словосполуки чи синтаксичні конструкціï healthy eating i healthy food кардинально відрізняються від їх еквівалентів, представлених на рисунках. Кожній з усталених англомовних графем знайдено відповідник, який відповідає загальній концепції здорового харчування. Такі приклади мають потужний прагматичний потенціал i семантичне наповнення завдяки тому, що сформовані шляхом використання саме тих елементів, які сприяють покращенню здоров'я, підтриманню належної фізичної форми. У процесі сприйняття інформації саме в такій формі у свідомості відбувається актуалізація прототипів продуктів харчування, спрацьовують зорові рецептори й унаслідок низки відповідних імпульсів збільшуються шанси щодо того, що продуценти схилятимуться до споживання саме тих продуктів харчування, які вважаються корисними.

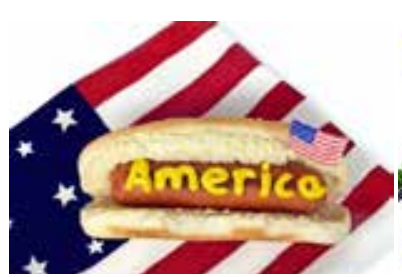

Puc. 3 [10]

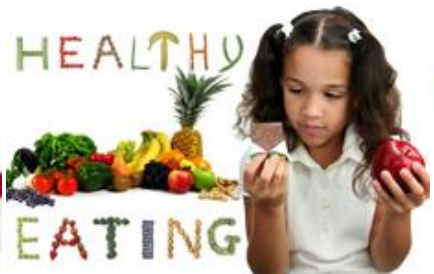

Pис. 4 [15]

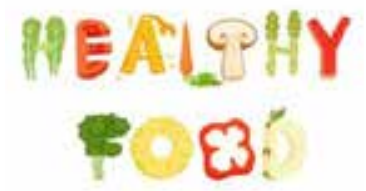

Pис. 5 [12]

Рис. 6 притаманні такі ж стратегії, що й рис. 3-5. Складники бургера, як i сама назва продукту, сформована у вигляді низки компонентів, які входять до його складу. Частина з них, як, наприклад, помідор і цибуля, мають звичний вигляд. Інші ж - кетчуп, гірчиця, сир, бекон - репрезентують 
назви цих же продуктів самими продуктами. На відміну від попередніх двох, що пропагують здоровий спосіб життя, бургер не $\epsilon$ тим продуктом, що має виключно приємні відгуки. Чимало людей усвідомлюють, що цей продукт шкідливий. Але такий спосіб репрезентації складу незвичний. Він досить креативний та апелює до любителів шкідливого фастфуду візуалізовано. Крізь назву, створену самими продуктами, наочно демонструється, що саме входить до його складу, і в такий спосіб стимулюється апетит.

Слід також зауважити, що кожній графемі на рис. 5 відповідає повноцінний продукт. В одному випадку це «їстівна графема», в іншому - це незалежний і самостійний продукт, що має свою назву. Графема “o" репрезентована шматком ананаса, який $\epsilon$ продуктом здорового харчування. Як самостійний продукт він має назву pineapple. Сукупність представлених продуктів харчування підсилює концепцію здорового харчування. У таких випадках продукти харчування завдяки своїй формі й розмірам можуть як уподібнюватися заміщуваному кодифікованому компонентові, так і існувати самостійно й бути незалежним, маючи свою назву. Як бачимо, такі невербальні засоби входять до складу мультимодальних графем, словосполук, речень завдяки формі, яку мають, і завдяки тому, що належать до продуктів здорового харчування, тобто відповідають авторському задуму. Наведені приклади свідчать про те, що таким графемам притаманна синонімія.

Отже, мультимодальні лексеми й синтаксичні конструкції можуть викликати у реципієнтів як позитивне, так і негативне ставлення. Усе залежить від продукту й ідеї, яку він покликаний візуалізувати. Особливо цікавими для лінгвістів видаються рис. 7 і 8 . Як бачимо, поруч із кодифікованими англійськими графемами використано продукти харчування, що, як і в попередніх випадках, заміщують графеми, які максимально уподібнені кодифікованим одиницям. У мультимодальній синтаксичній конструкції серед 15 графем - 9 англомовних кодифікованих, 6 «їстівних чи питних», умовно вигаданих. Поєднання звичних і незвичних одиниць свідчить про те, що нині можемо говорити про нові тенденції творення, сформовані шляхом комбінування кодифікованих графем та одиниць, які за формою та / або за змістом відповідають авторському задуму.

Досліджувана проблема нова в лінгвістичних студіях. Ураховуючи те, що кількість випадків, в яких використовують такі одиниці, зростає, постає необхідність говорити про зміни на рівні синтаксису й у сфері семантики, оскільки сукупність таких знаків не лише дублює зміст, а й поде- куди змінює значення. На рис. 7 бачимо бублик, бургер і банку напою (iх верхню частину) замість графеми "О", шматок піци - замість графеми "A", замість графеми "U" - чебуреки, а замість графеми "I" - морозиво. Такий випадок неординарний, оскільки присвячений пропагуванню нездорового харчування, пояснюючи, що кожен має право обирати, що саме споживати. Однак зміст стає зрозумілим виключно тоді, коли реципієнт знайомиться із частиною інформації, яку представлено вербально. YOU ARE TOO STUPID $\epsilon$ закликом не піддаватися переконанням дотримуватися здорового раціону. Завдяки знайомству із цим текстом зміст стає зрозумілим, як і вибір невербальних «їстівних графем і лексем».

Загальновідомий той факт, що споживання великої кількості продуктів швидкого харчування шкідливе для здоров'я. На рисунку бачимо саме ту їжу, яка не сприяє здоров'ю. Однак, ураховуючи мету повідомлення, їх вибір виправданий. Читаючи його, реципієнт мимоволі завдяки візуальному каналу фокусується на продуктах, які за бажанням може споживати. Дві лексеми містять по одній некодифікованій графемі, дві - по дві. Цікаве те, що в одній лексемі вміщено ще одну або дві, зміст яких очевидний завдяки їхній візуальній формі. Ці унаочнені продукти добре впізнавані, тому не викликають проблем у процесі сприйняття. Вони можуть функціювати самостійно, однак у наведених випадках вони виконують роль графем. Їх добір пояснюємо тим, що за формальними характеристиками вони максимально відповідають заміщуваному об'єктові. Ретельне прочитання дає змогу зрозуміти, що в одній лексемі натрапляємо на ще дві, які спершу виконують роль графем.

На рис. 8 реклама, присвячена соціальному дистанціюванню, - проблемі, особливо актуальній у період пандемії. Завдяки входженню до складу назви продукту "WHOPPER" цибулі замість графеми “О” в рекламі акцентують на тому, що в гамбургері міститься цибулі втричі більше. Графему "Е” замінено на три лінії, які можна уподібнити шарам, характерним для продукту. Неординарність такої презентації полягає в тому, що лексема містить не лише кільце цибулі, яке уподібнюється зазначеній лексемі, а й відповідає обраній тематиці. Доречне й заміщення графеми “Е” кількома лініями, що нагадують шари. У такому випадку йдеться про фокусування уваги на цибулі як складнику, що превалюють у гамбургері, і на шарах, 3 яких він складається. Як бачимо, заміщувані одиниці не завжди відповідають продуктам, на яких уважають за необхідне фокусуватися. На особливості рекламованого товару акцентовано завдяки графемі “Е”, а саме іiі заміщуваним шарам, на специфіці яких і зосереджено увагу. 


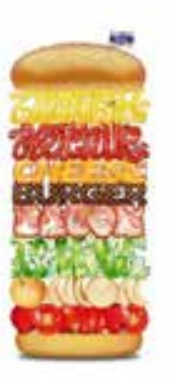

Рис. 6 [11]

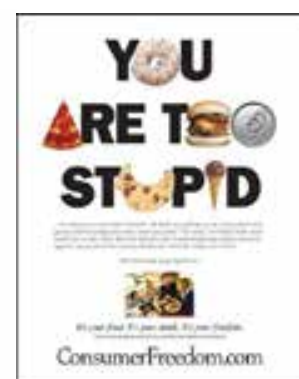

Pис. 7 [14]

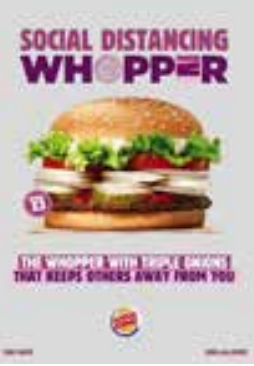

Рис. 8 [13]
На підставі здійсненого аналізу вважаємо, що мультимодальна графема - це компонент лексеми, яку максимально уподібнюють алфавітній позначці шляхом заміни або надавання їй специфічних ознак і можливостей шляхом використання одного чи кількох невербальних або паравербальних ресурсів замість однієї одиниці алфавіту. Мультимодальна лексема формується шляхом сполучення алфавітних графем і будьяких інших семіотичних ресурсів.

Висновки й перспективи подальших досліджень. Отже, на підставі проаналізованого корпусу ілюстративного матеріалу можемо вести мову про появу в сучасному англомовному комунікативному просторі мультимодальних графем, лексем, а отже, і синтаксичних конструкцій. Жоден із перелічених вище складників не має чітко усталеної форми, розмірів і, вочевидь, на відміну від алфавітних графем і створених на їх основі лексем не входить до жодного реєстру засобів, які мають комунікативне спрямування та загальновизнану кодифікацію. Тому такі засоби мають високий ступінь довільності. Їх добір залежить передусім від тематики матеріалу, який репрезентують, i можливості адаптувати їх до форми кодифікованої алфавітної графеми, що потребує заміщення. До складу однієї лексеми, як і однієї синтаксичної конструкції, може входити як один елемент невербальної природи, так і декілька одночасно.

Перспективними вважаємо подальші розвідки, спрямовані на дослідження мультимодальних графем, лексем і синтаксичних конструкцій, які уможливлять формування нових підходів до аналізу знаків і знакових систем.

\section{ЛІТЕРАТУРА}

1. Гусейнова И.А. Коммерческая реклама: современное состояние и тенденции развития. Рекламная коммуникация : лингвокультурный аспект : сборник обзоров / отв. ред. Н.Н. Трошина. Москва, 2011. С. 9-27.

2. Зирка В.В. Манипулятивные игры в рекламе: лингвистический аспект : монография. 3-е изд., испр. Москва : Книж. дом «Либроком», 2014. $260 \mathrm{c}$.
3. Лиса Н.С. Англійські рекламні знаки: особливості мовної реалізації. Іноземна філологія. 2001. Вип. 112. С. 127-133.

4. Макарук Л.Л. Мультимодальність сучасного англомовного масмедійного комунікативного простору : дис. ... д-ра. філол. наук : 10.02.04 ; Запорізький національний університет. Луцьк, Запоріжжя, 2019. 635 с.

5. Макарук Л.Л. Засоби та прийоми лінгвальної гри у сучасній англійській мові. Наукові записки. Серія "Філологічні науки» / Ніжинський державний університет імені Миколи Гоголя ; відп. ред. проф. Г.В. Самойленко. Ніжин : НДУ ім. М. Гоголя, 2014. Кн. 1. С. $142-148$.

6. Макарук Л.Л. Невербальні та паралінгвальні семіотичні ресурси у лінгвістичних студіях XX-XXI століть: прикладний аспект. Закарпатські філологічні студіі : збірник наукових праць ; Ужгородський національний університет. Ужгород, 2018. № 5. С. 66-72.

7. Медведева Е.В. Рекламная коммуникация. 3-е изд. Москва : Изд-во ЛКИ, 2008. 280 с.

8. Cook G. The Discourse of Advertising. 2nd ed. London : Routledge, 2001. 256 p.

9. Keiko T. Advertising Language. A Pragmatic Approach to Advertisements in Britain@Japan; London@New York. Printed@bound in Great Britain by T.J. International Ltd. Padstow; Cornwall, 1999. $148 \mathrm{p}$.

\section{СПИСОК ДЖЕРЕЛ}

\section{ІЛЮСТРАТИВНОГО МАТЕРІАЛУ}

10. Ads of the World. URL: https://www. adsoftheworld.com/media/print/burger_king _ burger (дата звернення: 12.07.2021).

11. Burgerlarised. URL: https://burgerlarised. wordpress.com/2014/01/29/more-burger-art-thebest-kind-of-art-obviously/ (дата звернення: 11.08.2021).

12. Delaware.gov. URL: https://dhss.delaware.gov/ $\mathrm{dph} / \mathrm{dpc} /$ healthychoices.html (дата звернення: 12.07.2021).

13. Pinterest. URL: https://www.pinterest.com/ pin/724024077586363641/ (дата звернення: 11.08.2021).

14. Quotes Gram.URL:https://quotesgram.com/img/ quotes-about-health-food-commercials/1388033/ (дата звернення: 11.08.2021).

15. Shutterstock. URL: https://www.shutterstock.com/ image-vector/healthy-food-vegetables-lettervector-lettering-396526735 (дата звернення: 12.07.2021).

16. Unboxsocial. URL: https://www.unboxsocial.com/ blog/wp-content/uploads/2019/02/3.png (дата звернення: 15.08.2021). 


\section{REFERENCES}

1. Huseinova, Y.A. (2011) Kommercheskaia reklama: sovremennoe sostoianye y tendentsyy razvytyia [Commercial advertising: current state and development trends]. Reklamnaia kommunykatsyia: lynhvokulturnyi aspekt : sb. obzorov / otv. red. N.N. Troshyna. Moskva, pp. 9-27 [in Russian].

2. Zyrka, V.V. (2014) Manipuliatyvni ihry v reklami: lynhvystycheskyi aspekt [Manipulative games in advertising: the linguistic aspect]. 3-e yzd., yspr. Moskva : Knyzh. dom "Lybrokom" [in Russian].

3. Lysa, N.S. (2001) Anhliiski reklamni znaky: osoblyvosti movnoi realizatsii. Inozemna filolohiia [English advertising signs: features of language implementation], vol. 112, pp. 127-133 [in Ukrainian].

4. Makaruk, L.L. (2019) Multymodalnist suchasnoho anhlomovnoho masmediinoho komunikatyvnoho prostoru [Multimodality of Modern English Mass Media Communicative Space] (PhD), Lutsk, Zaporizhzhia : Zaporizkyi natsionalnyi universytet [in Ukrainian].

5. Makaruk, L.L. (2014) Zasoby ta pryiomy linhvalnoi hry u suchasnii anhliiskii movi [Means and Techniques of Lingual Play in Modern English Langauge]. In Naukovi zapysky. Seriia "Filolohichni nauky" (Nizhynskyi derzhavnyi universytet imeni Mykoly Hoholia) / vidp. red. prof. H. V. Samoilenko. Nizhyn: NDU im. M. Hoholia, no. 1, pp. 142-148 [in Ukrainian].

6. Makaruk, L.L. (2018) Neverbalni ta paralinhvalni semiotychni resursy u linhvistychnykh studiiakh XX-XXI stolit: prykladnyi aspekt [Non-Verbal and Paralingual Semiotic Resources in Linguistic
Papers of the $20^{\text {th }}$ and $21^{\text {st }}$ Centuries: Applied Aspect]. In Zakarpatski filolohichni studii: zb. nauk. prats. Uzhhorodskyi natsionalnyi universytet. Uzhhorod, no. 5, pp. 66-72 [in Ukrainian].

7. Medvedeva, E.V. (2008) Reklamnaia kommunykatsyia. 3-e yzd. Moskva: Yzd-vo LKY [in Russian].

8. Cook, G. (2001) The Discourse of Advertising. 2nd ed. London : Routledge.

9. Keiko, T. (1999) Advertising Language. A Pragmatic Approach to Advertisements in Britain@Japan; London@New York. Printed@ bound in Great Britain by T. J. International Ltd. Padstow; Cornwall.

10. Ads of the World, available at: https://www. adsoftheworld.com/media/print/burger_king _ burger.

11. Burgerlarised, available at: https:// burgerlarised.wordpress.com/2014/01/29/moreburger-art-the-best-kind-of-art-obviously/.

12. Delaware.gov., available at: https:// dhss.delaware.gov/dph/dpc/healthychoices.html.

13. Pinterest, available at: https://www.pinterest.com/ pin/724024077586363641/.

14. Quotes Gram, available at: https:/quotesgram.com/ $\mathrm{img} /$ quotes-about-health-food-commer cials $/ 1388033 /$.

15. Shutterstock, available at: https://www. shutterstock.com/image-vector/healthy-foodvegetables-letter-vector-lettering-396526735.

16. Unboxsocial, available at: https://www. unboxsocial.com/blog/wp-content/uploads/ 2019/02/3.png. 